\title{
Social Effects of Mobile Technology on Generation Y Students
}

\author{
D. B Jordaan, J. Surujlal \\ North-West University, Faculty of Economic Sciences and Information Technology \\ PO Box 1174, Vanderbijlpark, 1900, Republic of South Africa \\ E-mail: Dawid.Jordaan@nwu.ac.za
}

\section{Doi:10.5901/mjss.2013.v4n11p282}

\begin{abstract}
The past decade has witnessed a dramatic invasion of mobile technology into the lives of people. Among those who appear to be most affected by this invasion are university students who are the most 'connected' generation. Research has found that in excess of $60 \%$ of students have access to either a desktop computer or a laptop and about $90 \%$ of them own a cellular phone. With university students being increasingly immersed in the latest social media such as Facebook, Sim City, MySpace and World of Wars there may possibly be serious social effects as a consequence. The purpose of this research is therefore to determine the social effects of mobile technology on Generation $Y$ students. A quantitative research approach involving the administration of a structured questionnaire to Generation $Y$ university students was used to collect data for the study. Data was collected by a trained research assistant who personally administered the questionnaire at the different university campuses. The data were analysed in the following ways: a descriptive analysis of the sample composition was undertaken and exploratory factor analysis was undertaken to establish the social effects of mobile technology. Seven factors, namely selfesteem and confidence, recreation, family interaction, social interaction, attentiveness, personal well-being and peer relationships were extracted. These factors are likely influence their lives as well as their behaviour. The overwhelming majority of respondents that own mobile mtechnology suggest how indispensible it has become as a mechanism to communicate, surf the net and engage in entertainment activities. Given the critical role that mobile technology plays in the lives of Generation $Y$ students' lives, it is important for them to create an appropriate balance between their usage, attention to their academic programmes and their social lives.
\end{abstract}

Keywords: Mobile technology, social effects, social networks

\section{Introduction}

The past decade has witnessed a dramatic invasion of technology into the lives of people. People form relationships when they are connected in networks and these networked relationships are termed social media. Social media is a time consuming activity which makes significant inroads into the lives of people (Safwat, Adel, George \& Sobhy, 2012; Wang, Chen \& Liang, 2011). One of the most popular social devices is the mobile phone.

Mobile technology has progressed from an instrument which was used only for making or receiving calls to that which allows the user to take pictures, send short text messages (SMS), surf the net (Internet), pay accounts and use it as a small portable computer (Dickson, 2010). Along with these amazing improvements which appear to be positive and offers many conveniences, a different picture of the technology has emerged. Research (e.g. Ha, Chin, Park, Ryu \& Yu, 2008; Yen, Hsiao, Ko, Yen, Huang, Liu, \& Wang, 2010; Wang et al., 2011) has found that the technology is capable of contributing to changing behaviour of individuals. Among these behaviours are health compromising behaviours which result in individuals foregoing opportunities to engage in physical activity, anti-social behaviours which result in spending less time with family and friends, neglect of important responsibilities such as academic and career responsibilities and disordered eating behaviours. In some instances, addiction to sexting has been reported (Weiss \& Samenow, 2010).

Hatch (2011) estimates that more than 500 million people keep in touch and communicate using social networking which is an indication that our lives become increasingly technology driven. As technology becomes more available and affordable adults get increasingly absorbed and reliant on technology and children become passionate users too. Rideout, Foehr \& Roberts (2010) found that young individuals are exposed to media an average of ten and three quarter hours per day. If multitasking is taken in consideration this average is seven and a half hours per day.

Among those who appear to be most affected by the invasion of mobile technology in their lives are university students who are the most 'connected' generation and described as techno-savvy (Shaw \& Fairhurst, 2008). An integral cohort of this group is Generation $Y$ students. In South Africa, this cohort represents a significant portion of the 
population. Although experts differ on the exact start and end dates of this age cohort, if one takes into account that Baby Boomers are those individuals born between 1946 and 1964 and Generation X those born between 1965 and 1979 (Schiffman \& Kanuk, 2007), then the starting date for Generation Y would be 1980. Research (Kotler, 2003; Schiffman \& Kanuk, 2007) suggests that the end date for this cohort is 1994. In the South Africa context this cohort is the first generation to grow up in the post-apartheid era (Bevan-Dye, Dhurup \& Surujlal, 2009). They have grown up in a multimedia rich world, which provides them with instant connection to global happenings and information, and allows for the creation of virtual social networks, such as Facebook, Sim City, MySpace and World of Wars.

\section{Problem statement}

Recent developments and advancement in communication technology has resulted in a dramatic evolution of the mobile industry. The use of mobile technology has increased so significantly that it has become one of the most dominant influences on society in current times (Campbell, 2005).

The mobile phone has become the most popular form of electronic communication which has become a status symbol for young people (Netsafe, 2005). It is a fashion symbol whose features, appearance and personalised accessories attest to the phone's status. Young people are reported to use this technology to organise and maintain social networks (Campbell, 2005; Williams \& Williams, 2005), go on the Internet (Enpocket, 2005) and communicate (Livingstone \& Bober, 2005).

Despite the numerous positive contributions and conveniences associated with the use of mobile technology, it is highly likely that these may compromise other important facets of young adults' lives. Billieux, Van der Linden, D'Acremont, Ceschi \& Zermatten (2006) argue that from a social point the status of mobile technology may change from one which supports social exchanges to that which clearly interferes with them. Little is known regarding the social effects of the use of mobile technology on Generation $Y$ university students. It is therefore important to understand the effects of mobile technology use among university students as these may impact on their academic and social life as well as their academic performance.

\section{Purpose of the study}

The purpose of the study was to investigate the social effects of mobile technology on Generation Y university students.

\section{Research methodology}

An extensive literature review on mobile technology and its influence on people's lives was undertaken. Arising from the literature review a questionnaire, which formed part of the empirical investigation, was developed to investigate the social effects of mobile technology on Generation Y university students.

\section{Sample and procedure}

The sample in the study comprised a non-probability convenience sample of 350 Generation $Y$ university students from university campuses in the Gauteng province of South Africa. The Generation Y cohort comprises individuals born between 1980 and 1994, and constitutes a significant percentage of the South African population. Students enrolled at universities constitute a particularly attractive sample to collect data from regarding mobile technology.

Data was collected by a trained research assistant who personally administered the questionnaire at the different university campuses. The questionnaire was administered over a period of two weeks before students sat for their semester exams. This period was chosen for the data collection as students did not have to attend classes and had available time to participate in the study.

At the outset participants were informed both verbally by the research assistant and through a covering letter of the purpose of the study. Ethical considerations such as the participants' right to anonymity, confidentiality, privacy or non-participation, informed consent and protection from discomfort, harm and victimisation were adhered to.

\section{Research instument}

The questionnaire used to collect data comprised three sections. Section A requested demographic information of the 
respondents, Section B requested information on the social effects of mobile technology and Section C investigated participants' dependence on mobile technology. The items in Section B were scored on a 5-point Likert scale which was graduated from 1 (strongly disagree) to 5 (strongly agree). This paper focuses on the social effects of mobile technology Two academics, one being an expert in mobile technology and the other in quantitative research reviewed the instrument for content validity. Furthermore, the instrument was pretested with a convenient sample of 10 Generation $Y$ students. This was done to ensure that there was no confusion or ambiguity regarding the understanding of the questions and to ascertain how long it took to complete the questionnaire. Arising from their feedback, minor revisions were made to the questionnaire. In order to test the reliability of the instrument a pilot test was conducted on a convenient sample of 60 university students.

\section{Data analysis}

The data were analysed in the following ways: a descriptive analysis of the sample composition was undertaken and exploratory factor analysis was undertaken to establish the social effects of mobile technology. The Statistical Packages for the Social Sciences (SPSS - version 21) was used to analyse the data.

\section{Results}

\subsection{Demographics}

Of the 350 questionnaires which were administered, 276 completed questionnaires were returned (response rate $=78.86 \%)$. More female respondents (60.4\%) than male respondents (39.6\%) completed the questionnaire.

With regard to ownership of technology $89.85 \%$ of the respondents indicated that they owned a personal computer or a laptop while almost all respondents (99.64\%) indicated that they have cell phones. The data thus revealed that the majority respondents have both a personal computer (or a laptop) and a cell phone. It is interesting to note that $82.60 \%$ of the respondents did not own tablets (or iPads), suggesting a preference for other types of mobile technology. The most common activities respondents engaged in when using the computer was surfing the Internet (72.81\%), followed by using e-mail (58.33\%), social networks (57.24\%), research activities $(42.39 \%)$, playing games $(41.30 \%)$, doing word processing (40.94\%) and visiting chat rooms (10.86\%). On the other hand, the most common activities respondents engaged in using their mobile phones were to make calls $(80.79 \%)$, followed by social networks $(73.91 \%)$, texting (56.88\%), surfing the Internet $(52.53 \%)$, using e-mail (42.75\%), visiting chat rooms (38.76\%) and playing games (32.97\%). With regard to their preference between computers and cell phones respondents indicated a preference for the cell phone rather than a computer to visit Facebook (51.81\%) and chat rooms (86.59\%). However, they preferred to use a computer for e-mails (65.21\%).

With regard to social aspects the results revealed that $2.54 \%$ have no friends, $8.69 \%$ have one to two friends, $19.92 \%$ have three to five friends, $16.30 \%$ have between 6 and ten friends and the majority (51.08\%) has more than ten friends. With regard to how Generation Y students spend their time when they are bored $46.01 \%$ indicated that they hang out with friends, $18.11 \%$ surf the Internet, $9.78 \%$ prefer to talk to family and $2.89 \%$ will call a friend. A small percentage (18.11\%) indicated that they choose to do other activities than the listed activities. When Generation Y students have a need to talk to friends about their emotions, family issues, friendships, and other related issues most respondents indicated that they preferred to do so face to face (51.44\%) and mobile instant messages (29.71\%) in contrast to Twitter, Facebook or direct telephone calls. When asked whether their parents complain about their use of computers or cell phones, the majority Generation Y students (59.05\%) indicated that their parents do not complain, while $40.57 \%$ parents do complain about their use of computers or cell phones. The main reason for the complaints is that use of computers or cell phones takes too much time which means less interaction with parents. Another reason why parents are concerned that the use of computers and cell phones was that it made less time available for studying. Bad behaviour, ethical issues, lack of focus on health-related activities and arguments with parents or family members also occurred as a result of their cell phone use.

\subsection{Exploratory factor analysis}

In the first instance, the appropriateness of factorability on the data set was established. The Bartlett's Test of Sphericity and the Kaiser-Meyer-Olkin (KMO) measure of sampling adequacy (MSA) was conducted on the data set. Both these 
tests $(\mathrm{KMO}=.762 ; \mathrm{sig} .=.000)$ indicated that the data was suitable for factor analysis. Principal component analysis (PCA) with varimax rotation was applied to the 30 items in Section B of the questionnaire. Varimax rotation, which reapportions variance among factors so that they become relatively equal in importance, was used to simplify factors by maximizing the variance loadings across variables (Gillespie, Derevensky \& Gupta, 2007). Using a minimum eigenvalue of 1 , the PCA extracted nine factors. Upon examination of the rotated factor matrix it was found that 6 items multi-loaded on more than one factor. These items were subsequently removed and the iterative process was then re-run to achieve a clear factor structure. Subsequently, seven factors which accounted for $61.36 \%$ of the overall variance in the scale item scores with two to five loadings on each factor were extracted. These factors included self-esteem and confidence ( 5 items), recreation (5 items), family interaction (4 items), social interaction (3 items), attentiveness (2 items), personal well-being (3 items) and peer relationships (2 items) Item reliability for each extracted factor was evaluated using Cronbach alpha (a). The factors' internal consistency ranged from $0.613-0.817$, which were close to or greater than the recommended significance level of 0.70 (Nunnally \& Bernstein, 1994) indicating an acceptable level of reliability. The rotated component matrix illustrating the resultant factors, eigenvalues and Cronbach alpha reliabilities provided in Table 1.

Table 1. Rotated factor loading matrix

\begin{tabular}{|c|c|c|c|c|c|c|c|}
\hline Item & $\begin{array}{c}\mathbf{F 1} \\
\text { Self-esteem } \\
\text { and } \\
\text { confidence }\end{array}$ & $\begin{array}{c}\text { F2 } \\
\text { Recreation }\end{array}$ & $\begin{array}{c}\text { F3 } \\
\text { Family } \\
\text { interaction }\end{array}$ & $\begin{array}{c}\text { F4 } \\
\text { Social } \\
\text { interaction }\end{array}$ & $\begin{array}{c}\text { F5 } \\
\text { Attention }\end{array}$ & $\begin{array}{c}\text { F6 } \\
\text { Personal } \\
\text { well-being }\end{array}$ & $\begin{array}{l}\mathbf{F 7} \\
\text { Friends }\end{array}$ \\
\hline $\begin{array}{l}\text { I enjoy performing in front of an } \\
\text { audience }\end{array}$ & .619 & .136 & .029 & -.052 & -.070 & -.001 & .066 \\
\hline $\begin{array}{l}\text { I find it easy to start a conversation } \\
\text { with a stranger. }\end{array}$ & .851 & .072 & .008 & .076 & .062 & .059 & -.084 \\
\hline $\begin{array}{l}\text { Interacting with people I have never } \\
\text { met before is easy for me. }\end{array}$ & .877 & .053 & -.079 & .049 & -.019. & .039 & -.010 \\
\hline $\begin{array}{l}\text { I can easily participate in an on- } \\
\text { going debate }\end{array}$ & .689 & .178 & .007 & .068 & -.100 & -.107 & .177 \\
\hline $\begin{array}{l}\text { I have no problems making new } \\
\text { friends }\end{array}$ & .708 & .042 & .180 & -.082 & .225 & .018 & .096 \\
\hline $\begin{array}{l}\text { I am satisfied with my extra- } \\
\text { curricular activities }\end{array}$ & .115 & .486 & .006 & .075 & .065 & .233 & .230 \\
\hline I exercise regularly (walk, gym, jog). & -.034 & .760 & .073 & -.071 & -.072 & .269 & -.081 \\
\hline $\begin{array}{l}\text { I regularly practise sports (swim, } \\
\text { football, hockey). }\end{array}$ & .118 & .762 & .063 & -.131 & -.153 & .106 & .008 \\
\hline I am very active in my daily life. & .180 & .701 & -.024 & .039 & .146 & .136 & .150 \\
\hline I practice my hobby regularly. & .163 & .726 & -.024 & .036 & .097 & -.078 & .141 \\
\hline $\begin{array}{l}\text { I am satisfied with my relationship } \\
\text { with my family. }\end{array}$ & .038 & -.025 & .657 & .175 & .135 & .193 & .287 \\
\hline $\begin{array}{l}\text { often discuss my problems and } \\
\text { concerns with my family. }\end{array}$ & .002 & .178 & .705 & .296 & -.030 & -.087 & -.086 \\
\hline My family supports me. & .071 & -.082 & .678 & .165 & .203 & -.005 & .095 \\
\hline I share my feelings with my family. & -.004 & .014 & .798 & .012 & -.081 & .161 & -.040 \\
\hline $\begin{array}{l}\text { I often watch television with my } \\
\text { family. }\end{array}$ & -.027 & -.138 & .073 & .798 & .030 & .085 & .025 \\
\hline I often eat with my family. & -.032 & -.033 & .240 & .782 & -.066 & .039 & .074 \\
\hline $\begin{array}{l}\text { I often interact with my brothers and } \\
\text { sisters. }\end{array}$ & .143 & .176 & .349 & .592 & .106 & .008 & -.049 \\
\hline $\begin{array}{l}\text { l listen to other people without } \\
\text { interrupting them. }\end{array}$ & -.021 & .103 & .122 & .040 & .799 & -.057 & .091 \\
\hline $\begin{array}{l}\text { I pay attention to other people's } \\
\text { discussions. }\end{array}$ & .025 & -.040 & .030 & -.020 & .801 & .078 & -.007 \\
\hline $\begin{array}{l}\text { am satisfied with my general } \\
\text { health. }\end{array}$ & .031 & .212 & .005 & .198 & .269 & .691 & .037 \\
\hline $\begin{array}{l}\text { I am satisfied with my academic } \\
\text { performance. }\end{array}$ & .071 & .129 & .112 & .080 & -.020 & .743 & .120 \\
\hline
\end{tabular}




\begin{tabular}{|l|c|c|c|c|c|c|c|}
\hline $\begin{array}{l}\text { I get eight hours of sleep every } \\
\text { night. }\end{array}$ & -.142 & .193 & .096 & -.144 & -.232 & .475 & .034 \\
\hline I often hang out with my friends. & .127 & .183 & -.018 & .130 & -.025 & -.034 & .808 \\
\hline $\begin{array}{l}\text { I am satisfied with my relationship } \\
\text { with my friends. }\end{array}$ & .050 & .131 & .186 & -.112 & .133 & .288 & .755 \\
\hline Eigenvalue & 4.300 & 2.915 & 2.405 & 1.598 & 1.221 & 1.209 & 1.079 \\
\hline$\%$ of variance explained & 12.563 & 11.349 & 9.725 & 7.899 & 6.838 & 6.692 & 6.294 \\
\hline Cumulative \% & 12.563 & 23.912 & 33.637 & 41.356 & 48.374 & 55.066 & 61.360 \\
\hline Reliability (Cronbach alpha) & .817 & .773 & .722 & .671 & .658 & .614 & .613 \\
\hline
\end{tabular}

\section{Discussion}

In the analysis of the social effects of mobile technology, seven factors were identified.

Factor 1, labelled self-esteem and confidence consisted of 5 items and accounted for $12.56 \%$ of the variance with an eigenvalue of 4.30 . This factor is concerned with the positive effect that mobile phones have in increasing selfesteem and confidence among users. It also has the potential to boost the morale and confidence of individuals (Metha, 2012). Chen, Hsieh \& Kinshuk (2008) reported that the use of mobile phones resulted in increased confidence and enjoyment among students. Hatch (2011), on the other hand, suggests that the more students are engaged in communicating through electronic media and less face-to-face, the more they begin to feel lonely, shy and depressed.

Factor 2, labelled recreation consisted of 5 items and accounted for $11.34 \%$ of the variance with an eigenvalue of 2.91. This factor is concerned with the effect that mobile technology is assumed to have on participation on recreation activities. While mobile technologies are used for recreation by many individuals, these technologies also have the potential to lure individuals away from other forms of recreation such as hobbies, sport, reading etc. Zhang (2012) opines that mobile technology relaxes people by providing them with a variety of entertainment. The authors argue that with the conveniences that mobile technology provides, a negative aspect is that it makes people lazier.

Factor 3, labelled family interaction consisted of 4 items and accounted for $9.72 \%$ of the variance with an eigenvalue of 2.40. This factor is concerned with individuals' interacting with family members. Contrary to the belief that mobile technology will cause members to drift apart, anecdotal evidence suggests that it actually brings family members closer. Mobile technology is the common ground many families use as a platform for discussion. Williams \& Williams (2005) posit that the introduction of mobile technology in the lives of families has detraditionalised family practices giving rise to 'new' parent and child relationships. The traditional family relationship is being replaced by more reflexive and democratic interactions.

Factor 4, labelled social interaction consisted of 3 items and accounted for $7.89 \%$ of the variance with an eigenvalue of 1.59. Social interaction, in the context of this study, is concerned with interaction with family members. Lanigan, Bold \& Chenoworth (2009) reported that $45 \%$ of the participants in their research indicated that mobile technology impacted their family relations positively while $24 \%$ indicated a mixed impact and $20 \%$ a negative impact.

Factor 5 , labelled attention consisted of 2 items and accounted for $6.38 \%$ of the variance with an eigenvalue of 1.22. This factor is concerned with one's ability to pay attention to others despite having one's mobile technology on oneself. Hatch (2011) posits that as one gets immersed in mobile technology, all activities associated with it become a constant distraction from other important activities. This may result in individuals focusing on many things at one time without paying full attention on any single thing.

Factor 6, labelled personal well-being consisted of 3 items and accounted for $6.69 \%$ of the variance with an eigenvalue of 1.20 . This factor is concerned with the effect that mobile technology has on one's physical and psychological well-being. Cotten (2008) commented that very little is known about the influence of mobile technology on the well-being of individuals. The author, however, is of the view that the impact of mobile technology may be mediated through other psycosocial aspects of individuals such as their self concepts, sense of mastery or self-efficacy over their lives. In some instances mobile technology has been found to influence physical well-being associated with musculoskeletal disorders resulting from sustained and awkward postures adopted by individuals while using mobile technology (Pitman, 2008).

Factor 7, labelled peer relationships consisted of 2 items and accounted for $6.29 \%$ of the variance with an eigenvalue of 1.07. This factor is concerned with the social effects of mobile technology on peer relationships. Williams \& Williams (2005) found that the effect of mobile technology on peer relationships has transformed peer groups into truly networked societies. It is indicative being part of the peer group. Campbell (2005) posits that ownership of a mobile phone signifies that one is socially connected, accessible and in demand and communication using the device is central 
to the identity of the user. The authors add that young people's usage of mobile phones affects the functionality or microcoordination of their social life.

\section{Limitations and implications for futher research}

A limitation of the study is the nature of the sampling method. A non-probabilty convenience sampling method in a single province in South Africa was used. Therefore caution should be exercised when generalising the social effects of mobile technology to other provinces. Notwithstanding this limitation, this study makes a significant contribution to the knowledge base of the social effects of mobile technology.

Arising from the results of the study are implications for further research. Extending the study to other provinces in South Africa and comparing the results may provide a more comprehensive illustration of the social effects of mobile technology on Generation Y students. The dearth of scholarly research about the influence of mobile technology on the well-being of Generation $Y$ students suggests that additional research in this area is warranted. Such research would expand one's understanding of the social effects of mobile technology.

\section{Conclusion}

The purpose of the study was to investigate the social effects of mobile technology on Generation $Y$ students. The study identified seven factors which were associated with mobile technology usage of Generation Y students. These factors are likely influence their lives as well as their behaviour. The overwhelming majority of respondents that own mobile mtechnology suggest how indispensible it has become as a mechanism to communicate, surf the net and engage in entertainment activities. Given the critical role that mobile technology plays in the lives of Generation Y students' lives, it is important for them to create an appropriate balance between their usage, attention to their academic programmes and their social lives.

\section{References}

Bevan-Dye, A.L., Dhurup, M. \& Surujlal, J. (2009). Black generation Y students' perceptions of national sport celebrity endorsers as role models. African Journal for Physical, Health Education, Recreation and Dance (AJPHERD), September 2009 (Supplement), $172-$ 188.

Billieux, J., Van Der Linden, M., D'Acremont, M., Ceschi, G. \& Zermatten, A. (2006). Does impulsivity relate to perceived dependence on and actual use of the mobile phone? Applied Cognitive. Psychology Journal, 21(5), 27-537.

Campbell, M. (2005). The impact of the mobile phone on young people's social life. Paper presented to the Social Change in the 21st Century Conference Centre for Social Change Research, 28 October 2005, Queensland University of Technology, Queensland: Australia. [Online] Available: http://eprints.qut.edu.au/3492/1/3492.pdf (April 24, 2013).

Chen, N.S., Hsieh, S.W. \& Kinshuk. K. (2008). Effects of short-term memory and content representation type on mobile language learning. Language Learning and Technology 12 (3),

93-113.

Cotten, S.R. (2008). Students' technology use and the impacts on well-being. [Online] Available: http://blog.reyjunco.com/pdf/Chapter4.pdf (April 13, 2013).

Dickson, D.M. (2010). Physiological and psychological consequences of forced mobile phone abstention. Unpublished MA Thesis. Texas State University, San Marcos: Texas.

Enpocket (2005). Mobile media monitor survey. [Online] Available: http://www.cellular-news.com/story/13286.php (May 13, 2013).

Gillespie, M., Derevensky, J. \& Gupta, R. (2007). The utility of outcome expectancies in the prediction of adolescent gambling behaviour. Journal of Gambling Issues, 19, 69-85.

Ha, J.H., Chin, B., Park, D., Ryu, S. \& Yu, J. (2008). Characteristics of excessive cellular phone use in Korean adolescents. Cyber Psychology \& Behavior, 11(6), 783-784.

Hatch, K.C. 2011. Determining the effects of technology on children. Senior Honours Project, Paper 260. [Online] Available: http://digitalcommunications.uri.edu/srhonorsprog/260 (April 12, 2013).

Kotler, P. (2003). Marketing Management (11 th ed.) (pp. 164-572). Upper Saddle River, NJ, USA: Prentice Hall.

Lanigan, J., Bold, M. \& Chenoweth, L. (2009). Computers in the family context: Perceived impact on family time and relationships. Family Science Review, 14(1), 16-32.

Livingstone, S., \& Bober, M. (2005). UK children go online: Final report of key project findings. London: LSE Report. [Online] Available: www.children-go-online.net (May 13, 2013).

Mehta, N.K. (2012). Mobile phone technology in English teaching: Causes \& concerns. Available at: http://site.iugaza.edu.ps/nmasri/files/2010/09/Mobile-Phone-Technology.pdf April 12, 2013).

Netsafe. (2005). The text generation: Mobile phones and New Zealand youth: A report of result from the internet Safety Group's survey 
of teenage mobile phone use. [Online] Available: http://www.netsafe.org.nz/Doc_Library/publications/text_generation_v2.pdf (May 13, 2013).

Nunnally, J.C. \& Bernstein, I.H. (1994). Psychometric theory (3rd ed.). New York: McGraw-Hill.

Pitman, S. (2008). The impact of media technologies on child development and wellbeing. [Online] Available: http://www.ozchild.org.au/userfiles/docs/ozchild/research-papers/lmpactOfElectronicMedia.pdf (April 12, 2013).

Rideout, V.J., Foehr, U.G. \& Roberts, D.F. 2010. Generation M2: Media in the lives of 8- to 18 Year-Olds. The Henry J. Kaiser Family Foundation. [Online] Available: http://www.kff.org/entmedia/upload/8010.pdf (May 28, 2013).

Safwat, C., Adel, H., George, M. \& Sobhy, S. (2012). The effect of technology on human behavior (a case study on BBC secondary school and the British University in Egypt), Cairo University. [Online] Available:

http://www.feps.edu.eg/en/departments/statistics/academicprograms/graduate/2011/ TheEffectof.pdf (May 18, 2013).

Schiffman, L.G. \& Kanuk, L.L. (2007). Consumer Behavior (9th ed.) (pp. 215-365). Upper Saddle River, NJ, USA: Pearson Prentice Hall.

Shaw, S. \& Fairhurst, D. (2008). Engaging a new generation of graduates. Education and Training, 50(5), 366-378.

Wang, Q., Chen, W. \& Liang, Y. (2011). The effects of social media on College students. MBA student Scholarship. Paper 5. Johnson \& Wales University. [Online] Available: http//scholararchieve.jwu.edu/mba_student/5 (May 04,2014).

Weiss, R. \& Samenow, C. (2010). Editorial: Smart phones, social networking, sexting and problematic sexual behaviors - A call for research. Sexual Addiction \& Compulsivity, 17, 241-246.

Williams, S. \& Williams, L. (2005). Space invaders: The negotiation of teenage boundaries through the mobile phone. The Sociological Review, 53, 314-331.

Yen, C., Hsiao, R., Ko, C., Yen, J., Huang, C., Liu, S. \& Wang, S. (2010). The relationships between body mass index and television viewing, internet use and cellular phone use: The moderating effects of socio-demographic characteristics and exercise. International Journal of Eating Disorders, 43(6), 565-571.

Zhang, G. (2012). The impact of mobile technology on people. [Online] Available: http://dmsp.ace.ed.ac.uk/blog/literaryhighstreet2 012/2012/04/27/the-impact-of-mobile-technology-on-peoples-live (April 13,2013). 